\title{
Tinjauan Terhadap Pendistribusian Zakat Profesi dalam Peningkatan Kesejahteraan Masyarakat ( Studi pada BAZNAS Kab. Maros)
}

\begin{abstract}
This study aimed to analyze the National Zakat Amil Agency (BAZNAS) of Maros Regency in distributing zakat. The research design was field research and employed qualitative descriptive method. The instruments of the study were interview guide, field note and recoding. The results of the study found that BAZNAS Maros district has distributed zakat in consumptive and productive forms, consumptive zakat given once in a while which was carried out in the month of Ramadan except for study completion assistance when given a request to apply through a proposal for study completion assistance, forthemore, for the productive zakat fund has been channeled every three months based on incoming request for assistance.
\end{abstract}

Keywords: Distributing Zakat, Profession Zakat, Consumptive, Productive.

\section{PENDAHULUAN}

Dewasa ini umat Islam berhadapan dengan berbagai macam problematika keuangan yang tidak bisa didiamkan begitu lama, sehingga tidak memberikan solusi. Salah satu problem yang dihadapi bangsa Indonesia saat ini yang berkaitan dengan keuangan adalah disparitas dan kemiskinan. Data terakhir pada bulan Maret 2016 tercatat jumlah penduduk miskin di Indonesia mencapai 28.005,41 ribu jiwa 2 (BPS: 2016). Kemiskinan merupakan ancaman yang membahayakan bangsa dalam berbagai tindakan kriminalitas akibat himpitan ekonomi, juga dapat mengganggu stabilitas perekonomian sebuah negara. Untuk mengatasi masalah ini dibutuhkan adanya sistem kesejahteraan yang berkelanjutan (Supanra, 2014). Melihat problematika ini, maka perlu untuk memperhatikan salah satu solusi dalam Islam untuk dapat menyejahterakan masyarakat yaitu dengan zakat, sedekah, dan wakaf yang berbentuk amal jariyah (Alfi, 2015).

Hal tersebut perlu untuk ditangani agar masyarakat tidak terguncang dalam urusan agamanya. Solusi terhadap problematika keuangan tersebut salah satunya adalah sistem zakat. Apabila pengelolaan zakat optimal tentu mempunyai pengaruh yang besar bagi kesejahteraan masyarakat.

Salah satu ajaran Islam yang bertujuan mengatasi kesenjangan dan gejolak sosial di masyarakat adalah zakat. (Patmawati, 2018) Zakat yang menjadi salah satu tiang penyangga bagi tegaknya Islam, serta menjadi kewajiban bagi pemeluknya membawa misi memperbaiki hubungan horisontal sesama manusia.Zakat merupakan salah satu rukun Islam,bahkan merupakan rukun kemasyarakatan yang paling tampak diantara semua rukun Islam, sebab di dalam zakat terdapat hak orang 
banyak yang terpikul pada pundak masing-masing individu. (Mujahidin, 2018).

Populasi Muslim yang begitu besar, Indonesia memiliki potensi zakat yang sangat besar. Menurut hasil survei Badan Amil Zakat Nasional (BAZNAS) dan IPB tahun 2015 dari potensi zakat trilliunan (217 Trilliun per tahunnya) (Taher, A. 2016), hal tersebut dapat terhimpun dari negeri yang berpenduduk sekitar 204 juta jiwa Muslim dari sekitar 255 juta jiwa penduduk indonesia(BPS, 2019).

Sementara itu, untuk menumbuhkan dan menggalakkan kesadaran berzakat di Indonesia, Pemerintah telah menerbitkan beberapa peraturan. Tentunya hal ini adalah salah satu upaya menjadikan zakat sebagai pengembangan ekonomi umat. Salah satunya yaitu UndangUndang Nomor 23 Tahun 2011 tentang Pengelolaan Zakat dan Undang-Undang Nomor 32 Tahun 2004.

Selain itu, pemerintah juga berupaya meningkatkan penghimpunan dana zakat dengan membentuk suatu lembaga khusus 'amil zakat yang memiliki sistem manajemen yang fungsional dan profesional. Hal tersebut dimaksudkan untuk mencapai hasil yang optimal dan efektif. Pengelolaan zakat oleh pemerintah adalah hal yang logis dengan melihat beberapa pertimbangan, yaitu untuk menjamin kepastian dan disiplin membayar zakat, menjaga perasaan rendah diri para mustahiq zakat apabila berhadapan langsung dengan wajib zakat (muzakki), mencapai efesiensi, efektifitas dan sasaran yang tepat dalam penggunaan harta zakat menurut prioritas yang ada pada suatu tempat, serta menunjukkan eksistensi Islam dalam memajukan kesejahteraan bangsa dan menumbuhkan semangat dalam penyelenggaraan negara dan pemerintahan yang stabil.

Pengelolaan zakat yang mengabaikan peran Kementerian agama bertentangan dengan prinsip syariah yang menghendaki ketegasan dan kepastian hukum. Pengelolaan zakat terkait dengan ketentuan syariah dan tidak bisa mengabaikan legalitas, akuntabilitas dan sistem pengawasan.(Sanep, Hairunnizam, \& Adnan, 2016)

Berdasarkan konteks inilah pengelolaan ZIS harus menerapkan sistem pengelolaan secara profesional, transparan, amanah, dan akuntabel. Implementasi manajemen moderen sejatinya menjadi referensi aplikatif minimal pada tataran planing, organizing, actuating, dan controling. Kondisi ini harus terbangun secara sistematis dan mewarnai kinerja lembaga sejak dari sistem pengumpulan, pendayagunaan, evaluasi bahkan analisis solusi dan tindak.

Oleh karena itu, salah satu bukti sejarah yang patut diteladani adalah pengelolaan zakat pada masa 'Umar bin 'Abdul 'Aziz. Ketika menunjuk para petugas yang amanah dan dapat dipercaya agar yang sudah mengeluarkan zakat mencatatkan resi tanda pelunasan untuk para muzakki sehingga mereka tidak harus membayar lagi melainkan telah berganti tahun. Setiap kelompok yang berhak menerima zakat harus bersumber dari penghimpunan zakat di daerahnya masing-masing kecuali mereka sudah berkecukupan.

Menurut penulis sejalan dengan pernyataan di atas bahwa zakat harus dikelolah oleh pemerintah. Hal ini karena pemerintah mempunyai 
kebijakan untuk mensejahterahkan masyarakat melalui dana ZIS tanpa aturan dan ikatan pemerintah masyarakat seolah-olah mengabaikan kewajibanya terhadap Tuhan dan sesama manusia. Namun sebaliknya apabila pemerintah kurang ahli mengelola lebih baik muzakkilangsung menyalurkan ZIS kepada mustahiq kemudian melaporkan ke pemerintah setempat.

Zakat yang dikelola pemerintah sekarang ini masih terbatas pada zakat profesi yang diambil dari para pegawai negeri sipil baik melalui pemotongan langsung maupun tidak langsung.

BAZNAS Kabupaten Maros juga mengelola zakat dari zakat profesi yang diambil dari para pegawai negeri sipil di kabupaten Maros. Pengelolaan zakat profesi yang dilakukan BAZNAS kabupaten Maros terus mengalami peningkatan dengan terus melakukan sosialisasi dan kampanye dengan memasang beragam spanduk dan baliho diberbagai titik dikabupaten maros (baznas-Maros.com. 2019), guna menumbuhkan minat, antusiasme dan kesadaran warga dalam menunaikan Zakat.

Mengingat zakat ini adalah merupakan kewajiban dari Allah Swt. Juga merupakan amanat Undang-undang no 23 tahun 2011 sehingga setiap instansi baik vertikal maupun horisontal, pusat maupun daerah wajib membentuk BAZNAS, dari sini peneliti penting untuk melakukan penelitian sejauhmana usaha yang dilakukan oleh BAZNAS dalam mengelola zakat sebagai amanat undang-undang, sehingga kita akan melihat gambaran secara rinci pengelolaan zakat terutama aspek pendistribusiannya.
Tujuan dari penelitian ini adalah untuk menganalisis pendistribusian zakat yang dilakukan oleh BAZNAS Kabupaten Maros, serta langkahlangkah yang dilakukan untuk mensejahterahkan masyarakat miskin melalui pendistribusian zakat ini.

\section{KAJIAN TEORI \\ Zakat Profesi}

Zakat penghasilan atau zakat profesi adalah suatu istilah yang muncul dewasa ini. Adapun istilah ulama salaf, bagi zakat atas penghasilan atau profesi biasanya disebut dengan al-Mal Mustafad. Yang termasuk dalam kategori zakat al-Mal Mustafad. Yang termasuk dalam kategori zakatalMustafad adalah pendapatan yang dihasilkan dari profesi non zakat yang dijalani, seperti gaji pegawai/swasta, konsultan, dokter, dan lain-lain.

Qardhawi (2011) menyatakan bahwa barangkali bentuk penghasilan yang paling menjolok pada zaman sekarang ini adalah apa yang diperoleh dari pekerjaan dan profesinya. Selanjutnya menurut Yusuf alQardhawi, bahwasanya pekerjaan yang menghasilkan uang ada dua macam, yaitu pertama adalah pekerjaan yang dikerjakan berkat kecekatan tangan ataupun otak. Penghasilan yang diperoleh dengan cara ini merupakan penghasilan profesional, seperti penghasilan dokter, insinyur, advokat, seniman, dan lainnya. Kedua, adalah pekerjaan yang dikerjakan seseorang buat pihak lain, baik pemerintah, perusahaan, maupun perorangan dengan memperoleh upah, yang diberikan dengan tangan, otak, ataupun keduaduanya. Penghasilan dari pekerjaan seperti itu berupa, gaji, upah, ataupun honorium.

Jurnal Ekonomi dan Bisnis Islam |157 
Terdapat perbedaan pendapat di kalangan para ulama tentang hukum zakat profesi ini. Sebagian ulama berpendapat, bahwa zakat profesi tidak didukung oleh adanya dalil yang jelas, baik yang berasal dari Alquran maupun hadis. Bahkan Rasulullah SAW tidak pernah menerapkan zakat profesi di masa beliau masih hidup, sementara sekian jenis profesi dan spesialisasi telah ada. Bahkan sampai sekian abad kemudian, umumnya para ulama pun tidak pernah menuliskan adanya zakat profesi di dalam kitab-kitab fiqih dalam bab khusus.

Qardhawi (2011) menyebut istilah profesi dengan kasb al-Amal wa almihana alhurrah, yaitu setiap pekerjaan atau usaha yang dikerjakan sendiri tanpa tergantung pada orang lain atas kemampuan, keterampilan, atau pemikiran yang dilakukan untuk orang atau badan lain dengan menerima imbalan.

Sebagian dari nama dan macam ragam sumber harta kekayaan tersebut merupakan rincian atas pengertian amwal dalam beberapa ayat Alquran dan penjabaran dari firman Allah, QS. alBaqarah 2: 267.

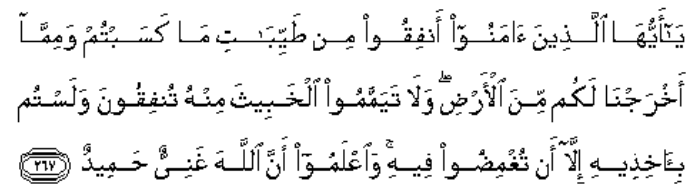

Terjemahnya:"Hai orang-orang yang beriman, nafkahkanlah (di jalan Allah) sebagian dari hasil usahamu yang baikbaik dan sebagian dari apa yang Kami keluarkan dari bumi untuk kamu. Dan janganlah kamu memilih yang burukburuk lalu kamu menafkahkan daripadanya, Padahal kamu sendiri tidak mau mengambilnya melainkan dengan memincingkan mata terhadapnya. Dan ketahuilah, bahwa Allah Maha Kaya lagi Maha Terpuji."(QS. al-Baqarah/2: 267)

Dalam ayat tersebut di atas, terdapat kata min thayyibat ma kasabtum yang berarti hasil usaha yang baik-baik dari segi kualitasnya dan dari segi prosedur memperolehnya.

a.

Oleh karena itu, maka zakat yang berasal dari al-Mal al-Mustafad ini sudah disepakati oleh jama'ah sahabat dan ulama-ulama berikutnya untuk wajib dikenakan zakat.

Perbedaan pendapat hanya tentang persyaratan haul. Berkaitan degan haul maka ditemukan sejumlah pendapat (Az-Zuhaili, W. 2011):

a. Menurut Abu hanifah, mal mustafad tidak dizakati sebelum sempurna satu tahun di tangan pemiliknya, kecuali apabila pemiliknya mempunyai harta sejenis yang pada permulaan tahun sudah mencapai satu nishab, maka almal al-mustafad itu dipungut zakatnya bersamaan.

b. Menurut Imam Malik, al-mal almustafad tidak dizakati sebelum semprna setahun, baik sipemilik mempunyai harta yang sejenis, kecuali tentang ternak.

c. Menurut Imam Syafi'i al-mal almustafad ini tidak dizakati sebelum setahun, meskipun sipemilik mempunyai harta yang sejenis, kecuali anak ternaknya sendiri, maka mal mustafad yang berupa anak ternaknya sendiri dizakati mengikuti induknya.

d. Menurut Daud al-Zahiri, al-mal almustafad wajib zakat tanpa syarat satu tahun.

e. Menurut Ibnu Hazm, beliau mengkritik penfsiran ulama sebelumnya, Ia mengatakan bahwa 
pendapat-pendapat tersebut tanpa dalil sama sekali. Menurut dia, semua harta itu disyaratkan setahun, baik harta al-mal al-mastafad maupun tidak.

f. Menurut Yusuf al-Qardawi, bahwa al-mal al-mustafad seperti gaji pegawai upah buruh, penghasilan dokter, pengacara, pemborong, pengusaha rental mobil, dan penghasilan lainnya wajib bagi mereka dikenakan zakat dan tidak pula disyaratkan sampai setahun, akan tetapi dizakati waktu menerima penghasilan tersebut.Kalau kita melihat sejarah pelaksanaan zakat profesi ini, sebenarnya telah diterpkan pada masa Khalifah Abu Bakar dah Khalifah Umar bin Affan kemudian diterapkan secara resmi oleh Khalifah Umar bin Abdul Aziz pada abad ke II H, yaitu terhadap para pejabat di lingkungan kerajaan dengan memotong gaji dan penghasilan mereka sebagai zakat, (Hilman, 2018).

\section{METODE PENELITIAN}

Metode penelitian yang digunakan dalam penelitian ini adalah kualitatif lapangan, atau field researchyang berlokasi di BAZNAS Kabupaten Maros selama kurang lebih 3 bulan di lokasi.Teknik pengumpulan data yang digunakan adalah Observasi, wawancara dan dokumentasi. Sedangkan Data yang dikumpulkan berupa data primer bersumber dari hasil wawancara dengan beberapa informan meliputipejabat pemerintah kabupaten Maros,pengurus BAZNAS kabupaten Maros, cendekiawan muslim, dan data sekunder bersumber dari buku, artikel, dan lain-lain. tokoh Agama dan masyarakat. Sedangkan untuk mengecek keabsahan data menggunakan teknik triangulasi, yakni teknik pemeriksaan keabsahan data memanfaatkan sesuatu yang lain di luar data untuk keperluan pengecekan atau pembanding terhadap data yang diperoses.

\section{HASIL PENELITIAN DAN PEMBAHASAN \\ Alokasi Pendistribusian Zakat profesi}

Undang-Undang Nomor 23 tahun 2011 tentang pengelolaan zakat telah menentukan bahwa pengelola zakat adalah pemerintah, melalui Badan Amil Zakat yang dibentuknya lalu dikukuhkan oleh pemerintah. Pengelola zakat tersebut, baik Badan Amil Zakat maupun Lembaga Amil Zakat, bertugas mengumpulkan dana zakat dan dana lainnya sekaligus mendistribusikan dan mendayagunakannya, bahkan juga melaporkan dan mempertanggung jawabkan pelaksanaan pengelolaan zakat.

Perolehan dana zakat profesi dari muzakki yang dikumpulkan oleh BAZNAS baik diperoleh dari muzakki secara langsung maupun hasil pengumpulan dari UPZ-UPZ yang ada kemudian disimpan didalam rekening BAZNAS. Tahap selanjutnya adalah penentuan para mustahiq yang berhak menerima zakat baik yang sifatnya konsumtif maupun yang produktif. Untuk pendistribusian dan pendayagunaan zakat profesi maka BAZNAS membentuk tim pendataan mustahik. Tim ini bertugas untuk mendata mustahik diseluruh kecamatan yang ada dikabupaten Maros dengan tetap memprioritaskan kelompok fakir miskin. Tim pendataan mustahik perkecamatan. 
Tim inilah yang mendata sekaligus mensurvei seluruh mustahik di berbagai kecamatan untuk dimusyawarahkan siapa yang paling layak untuk diberikan zakat, mustahik yang dimaksud adalah masyarakat miskin yang kurang mampu secara ekonomi ada beberapa kriteria kemiskinan menurut standar Badan Pusat Statistik:

1. Luas lantai bangunan tempat tinggal kurang dari $8 \mathrm{~m} 2$ per orang

2. Jenis lantai tempat tinggal terbuat dari tanah/bambu/kayu murahan

3. Jenis dinding tempat tinggal dari bambu/ rumbia/ kayu berkualitas rendah/tembok tanpa diplester.

4. Tidak memiliki fasilitas buang air besar/ bersama-sama dengan rumah tangga lain.

5. Sumber penerangan rumah tangga tidak menggunakan listrik.

6. Sumber air minum berasal dari sumur/ mata air tidak terlindung/ sungai/ air hujan.

7. Bahan bakar untuk memasak seharihari adalah kayu bakar/ arang/ minyak tanah

8. Hanya mengkonsumsi daging/ susu/ayam dalam satu kali seminggu.

9. Hanya membeli satu stel pakaian baru dalam setahun

10. Hanya sanggup makan sebanyak satu/ dua kali dalam sehari

11. Tidak sanggup membayar biaya pengobatan di puskesmas/ poliklinik

12. Sumber penghasilan kepala rumah tangga adalah: petani dengan luas lahan 500m2, buruh tani, nelayan, buruh bangunan, buruh perkebunan dan atau pekerjaan lainnya dengan pendapatan dibawah Rp. 600.000,per bulan
13. Pendidikan tertinggi kepala rumah tangga: tidak sekolah/ tidak tamat $\mathrm{SD} /$ tamat SD.

14. Tidak memiliki tabungan/ barang yang mudah dijual dengan minimal Rp. 500.000,- seperti sepeda motor kredit/ non kredit, emas, ternak, kapal motor, atau barang modal lainnya.

Standar ini bisa menjadi acuan untuk penetapan keluarga miskin, namun tentu saja BAZNAS bisa membuat kriteria miskin sesuai daerah masing-masing. Karena standar kemiskinan suatu daerah berbeda dengan daerah lain. Maka standar kemiskinan adalah kembali kepada 'urf suatu daerah dengan mempertimbangkan maslahat.

Beberapa prinsip yang perlu diperhatikan dalam pendistribusian yaitu

1) Diberikan kepada delapan asnaf;

2) Manfaat zakat itu dapat diterima dan dirasakan manfaatnya;

3) Sesuai dengan keperluan mustahiq (konsumtif dan produktif).

Pendayagunaan zakat yang dikumpulkan oleh badan amil zakat diarahkan kepada program-program yang memberi manfaat jangka panjang untuk perbaikan kesejateraan mustahiq. Pendayagunaan zakat pada prinsipnya bertujuan untuk meningkatkan status mustahiq menjadi muzakki, melalui peningkatan kualitas sumber daya manusia dan pemberdayaan sosial serta pengembangan ekonomi (Yoghi Citra, 2015)

Menurut Said Patombongi (Patombongi, 2015) selaku wakil ketua BAZNAS untuk penyalurannya BAZNAS maros akan mengalokasikan dengan komposisi sebagai berikut terdiri 
dari zakat produktif $40 \%$ dan $60 \%$ zakat emergency.

Zakat yang terkumpul dimasukkan kedalam rekening BAZNAS kabupaten Maros. Mengingat bahwa untuk biaya operasional BAZNAS adalah Anggaran Pendapatan Belanja Daerah (APBD) meskipun masih diperoleh dari bantuan sosial atau hibah, dengan BAZNAS mengajukan proposal bantuan biaya operasional BAZNAS kabupaten Maros, pemerintah kab. Maros pada tahun ini memberikan bantuan biaya operasional sebesar Rp. 300.000.000,- (tiga ratus juta rupiah) Maka hampir seluruh dana zakat yang diperoleh dialokasikan untuk mustahiq(Said, 2015).

\section{Penditribusian dan Pendayagunaan Zakat Profesi}

Dalam pendistribusian zakat profesi yang dilakukan oleh Badan Amil Zakat (BAZNAS) kabupaten Maros dibagi menjadi beberapa jangka waktu, yaitu:

\section{a. setahun sekali}

pelaksanaan distribusi zakat profesi dilaksanakan secara rutin tiap setahun sekali yang dilaksanakan pada bulan ramad \}an di 14 kecamatan yang terdiri dari 80 Desa dan 23 Kelurahan yang ada di kabupaten

Maros("http://maroskab.go.id), jumlah dana yang didistribusikan pada tahap awal sebesar Rp. 360.500.000,- (tiga ratus enam puluh juta lima ratus ribu rupiah)kepada 1030 orang fakir miskin dengan 10 orang tiap desa atau kelurahan.Pendistribusian dihadiri oleh Bupati/ yang mewakili, tokoh masyarakat dan pengurus BAZNAS kabupaten Maros. Dan dibagikan di lingkungan masing-masing (Staff, 2015). Melihat dari pendistribusian dana konsumtif untuk fakir miskin dengan masih dalam bentuk bantuan sesaat tentu masih sangat jauh dari harapan bahwa mereka diberdayakan dengan zakat ini atau membantu mereka dari kesulitan ekonomi.(Irfan Syauki, 2015) Oleh karena itu kedepan BAZNAS Kabupaten Maros bisa memberikan mereka dalam bentuk santunan yang diberikan setiap bulan sehingga mereka betul-betul merasa terbantu dengan dana zakat, tentu saja harus disertai dengan pengumpulan zakat yang optimal yaitu dengan pemberdayaan potensi zakat yang ada di kabupaten Maros. Potensi zakat yang sangat besar di kabupaten Maros bisa menjadi harapan untuk membangun ekonomi kerakyatan.

b. Tiga bulan sekali

Adapun pemberian bantuan penyelesaian s1 dan s2 serta bantuan dana produktif berupa bantuan modal usaha didistribusikan berdasarkan permohonan yang masuk setelah dimusyawarahkan oleh pengurus selanjutnya ditentukanlah jadwal pendistribusiannya. Adapun pendistribusiannya dilakukan di kantor Badan Amil Zakat Kabupaten Maros, Jl. Kemiri no. 13 Maros.

c. Insidentil

Pelaksanaan pendistribusian secara insidentil dilaksanakan setiap ada bencana alam yang datang secara tiba-tiba seperti terjadi kebanjiran, rumah tertimpa pohon, terkena angin puting beliung dan lain-lainnya. 
Pelaksanaannya korban atau pemerintah setempat mengajukan permohonan proposal kepada BAZNAS kabupaten Maros dari permohonan tersebut kemudian dikeluarkan zakat profesi kepada korban yang menderita akibat korban bencana alam tersebut.

Adapun sasaran yang dituju pendistribusian zakat adalah dengan berpedoman pada surah al-Taubah ayat 60 dengan memperhatikan beberapa prinsip ini yaitu (1) Diberikan kepada delapan asnaf; (2) Manfaat zakat itu dapat diterima dan dirasakan manfaatnya; (3) Sesuai dengan keperluan mustahiq (konsumtif dan produktif).

Pendayagunaan hasil pengumpulan zakat untuk mustahiq dilakukan berdasarkan persyaratan sebagai berikut hasil pendataan dan penelitian kebenaran mustahiq delapan ashnaf yaitu fakir, miskin, amilmuallaf, riqabgharim, sabilillah, dan ibnu sabil; mendahulukan orang-orang paling tidak berdaya memenuhi kebutuhan dasar secara ekonomi dan sangat memerlukan bantuan; mendahulukan mustahiq dalam wilayah masing-masing.

Pendayagunaan zakat yang dikumpulkan oleh badan amil zakat diarahkan kepada program-program yang memberi manfaat jangka panjang untuk perbaikan kesejateraan mustahiq. Pendayagunaan zakat pada prinsipnya bertujuan untuk meningkatkan status mustahiq menjadi muzakki, melalui peningkatan kualitas sumber daya manusia dan pemberdayaan sosial serta pengembangan ekonomi.

Sedangkan berdasarkan klasifikasi penggunaan dana zakat pendistribusian zakat profesi yang dilakukan oleh Badan Amil Zakat (BAZNAS) kabupaten Maros dibagi menjadi dua, yaiu zakat yang diguanakan untuk konsumtif dan produktif.

a. Pemberdayaan Dana Konsumtif

Dana yang dapat didistribusikan dalam bentuk pemberdayaan konsumtif ini hanyalah dana zakat, tidak dana yang lain. Dalam pendistribusian dana zakat kepada mustahiq ada tiga sifat, yaitu bersifat hibah (pemberian) dan memperhatikan skala prioritas kebutuhan mustahiq di wilayah masing-masing; bersifat bantuan, yaitu membantu mustahiq dalam menyelesaikan atau mengurangi masalah yang sangat mendesak/ darurat; bersifat pemberdayaan, yaitu membantu mustahiq untuk meningkatkan kesejahteraannya, baik secara perorangan maupun berkelompok melalui program atau kegiatan yang berkesinambungan dengan dana bergulir untuk memberikan kesempatan penerima lain yang lebih banyak. Dana-dana zakat yang didistribusikan dalam bentuk konsumtif dapat dibedakan dalam dua sifat, yakni konsumtif tradisional dan konsumtif kreatif.

Pada pendayagunaan zakat untuk konsumtif tradisional, zakat diberikan kepada mustahiq secara langsung untuk kebutuhan konsumsi sehari-hari seperti pembagian zakat fitrah berupa beras dan uang kepada fakir miskin setiap idul fitri atau pembagian zakat mal untuk fakir miskin yang sangat membutuhkan karena ketiadaan pangan atau karena mengalami musibah. Pola ini merupakan program jangka pendek 
dalam mengatasi permasalahan umat yang dapat dalam bentuk pembagian bahan makanan secara langsung; pemberian uang untuk pembelian kebutuhan sehari-hari; pemberian sandang; pemberian obat-obatan; pemberian uang untuk menyewa rumah; pemberian tempat tinggal.

Sedangkan pendayagunaan zakat untuk konsumtif kreatif, Zakat diwujudkan dalam bentuk barang konsumtif dan digunakan untuk membantu fakir miskin dalam mengatasi permasalahan sosial dan ekonomi yang dihadapinya. Bantuan tersebut antara lain berupa pemberian beasiswa untuk anak keluarga miskin; alat-alat sekolah untuk para pelajar; bantuan sarana ibadah seperti sarung, mukena, dan sajadah; bantuan alat pertanian seperti cangkul untuk petani; bantuan sarana usaha untuk pedagang kecil seperti gerobak jualan.

b. pemberdayaan Zakat Produktif

Pemberdayaan zakat, infak, sadaqah, hibah, warisan, dan kafarat diutamakan untuk usaha yang produktif dengan tujuan agar dapat meningkatkan kesejahteraan masyarakat (Akhmad, 2013).

Pendayagunaan hasil pengumpulan zakat untuk usaha yang produktif dilakukan berdasarkan persyaratan sebagai berikut terdapat usaha-usaha nyata yang berpeluang menguntungkan dan mendapat persetujuan dari pengurus BAZNAS.

Penyaluran/pendistribusian zakat dalam bentuk ini bersifat bantuan pemberdayaan melalui program atau kegiatan yang berkesinambungan dengan dana bergulir untuk memberi kesempatan penerima dana lebih banyak lagi.

Prosedur pendayagunaan hasil pengumpulan zakat untuk usaha prooduktif ditetapkan sebagai berikut melakukan study kelayakan; menetapkan jenis usaha produktif; melakukan bimbingan dan penyuluhan; melakukan pemantauan, pengendalian, dan pengawasan; mengadakan evaluasi; membuat pelaporan.

Terdapat dua bentuk pemberdayaan zakat produktif, yaitu produktif konvensional dan produktif kreatif.

Pertama, Zakat Produktif konvensional yang diberikan dalam bentuk barang-barang produktif yang dengan menggunakan barang-barang tersebut para mustahiq dapat menciptakan suatu usaha seperti pemberian bantuan hewan ternak kambing, sapi perah atau sapi untuk membajak sawah; pemberian bantuan sarana untuk perajin seperti alat pertukangan dan mesin jahit; pemberian bantuan sarana berupa lahan sawah/kebun untuk digarap (sawah atau kebun percontohan), penyewaan kios/tempat usaha.

Kedua, Zakat Produktif kreatif yang diwujudkan dalam bentuk pemberian modal bergulir atau untuk permodalan proyek sosial seperti pemberian modal usaha untuk membantu atau bagi pengembangan usaha bagi para pedagang kecil; membangun sekolah didaerah pemukiman miskin; membangun sarana kesehatan di daerah kumuh; membangun tempat ibadah dan sarana pendidikan keterampilan bagi masyarakat miskin. 
Adapun besaran dana yang diterima untuk zakat produktif maksimal 5 juta(Suradi, 2015), dan yang baru diimplementasikan di Badan Amil Zakat (BAZNAS) kabupaten Maros masih dana produktif kreatif yaitu berupa bantuan modal usaha, tetapi bantuan ini sifatnya pinjaman tanpa bunga yang mesti dikembalikan oleh peminjam kecuali peminjam itu tidak mampu mengembalikannya ataupun dengan alasan yang lain seperti meninggal dll.

Dari data yang peneliti peroleh dari hasil pendistribusian zakat profesi di kabupaten Maros, dari data yang peneliti peroleh untuk bantuan produktif itu ada 39 mustahiq zakat yang menerima bantuan tambahan modal mulai dari 1 juta rupiah sampai 5 juta rupiah, ada 12 orang menerima bantuan sebesar 1 juta rupiah, 2 orang memperoleh 1,5 juta rupiah, 5 orang memperoleh 2 juta rupiah, 1 orang menerima 2,5 juta rupiah, 8 orang menerima 3 juta rupiah, dan 4 orang yang memperoleh 5 juta rupiah, dari 85.500.000 rupiah yang dialokasikan untuk zakat produktif. BAZNAS dalam menetapkan nominal bantuan kepada mustahik dengan meihat potensi usaha yang dilakukan oleh calon penerima. Tidak sampai memberikan bantuan saja tetapi BAZNAS juga melakukan pendampingan dan pembinaan terhadap penerima bantuan sehingga mustahik benar-benar diberdayakan. BAZNAS sudah melakukan upaya untuk memberdayakan dana zakat yang terkumpul dengan mendistrbusikannya tidak hanya dalam bentuk konsumtif tapi juga dalam bentuk produktif. Bagi masyarakat yang memiliki kemampuan untuk bekerja dan berusaha maka seharusnya mereka diberikan zakat dalam bentuk yang produktif, sehingga tidak menjadikan zakat sebagai gantungan hidup. Sehingga tujuan zakat yaitu mengangkat derajat mereka dari mustahiq menjadi muzakki. Namun tentu saja butuh proses yang panjang untuk berevolusi dari mustahiq menjadi muzakki. Melihat dari pendistribusian zakat produktif yang masih sangat sedikit maksimal 5 juta bahkan kebanyakan dari para penerima zakat produktif ini hanya menerima 1 juta rupiah, maka masih sulit melihat mereka berevolusi menjadi muzakki. Tetapi mereka sudah sangat terbantu dengan bantuan modal ini karena dengan bantuan ini mereka bisa menambah modal usaha mereka, sehingga mereka tidak lagi mengaharapkan dana zakat untuk kebutuhan sehari-hari mereka(Mardiani, 2016).

zakat merupakan pranata keagamaan untuk mewujudkan keadilan sosial bagi masyarakat dengan memperhatikan masyarakat yang kurang mampu dan hasil pengumpulan zakat merupakan sumber dana yang potensial bagi upaya mewujudkan kesejahteraan masyarakat (Nasher, 2019).

Zakat merupakan manifestasi dari kegotongroyongan antara orang kaya dengan fakir miskin. Pemberdayaan zakat merupakan perlindungan bagi masyarakat dari bencana kemasyarakatan, yaitu kemiskinan, (Sartika, 2018) kelemahan baik fisik maupun mental.

Lembaga "zakat" merupakan sarana distribusi kekayaan di dalam ajaran Islam yang merupakan kewajiban kolektif perekonomian umat Islam. Zakat merupakan komitmen seorang 
muslim dalam bidang sosial-ekonomi yang tidak terhindarkan untuk memenuhi kebutuhan pokok bagi semua orang, tanpa harus meletakkan beban pada kas negara semata, sebagaimana yang dilaksanakan dalam sistem sosialisme dan negara kesejahteraan modern.

BAZNAS kabupaten Maros melalui dana zakat yang terkumpul berupaya untuk memberdayakannya dengan memeberikan bantuan modal usaha kepada para mustahiq yang memiliki potensi untuk berusaha dengan memiliki keterampilan seperti menjahit, membuat kue, dan usaha-usaha yang bisa menunjang kehidupan para mustahiq dengan tidak lagi menggantungkan hidupnya kepada bantuan orang lain.

Yang lebih menggembirakan lagi dengan bantuan modal ini, ketika mereka melakukan pengembalian dengan mengansur pembayarannya mereka menyertakan infak, karena harta mereka belum sampai haul dan nisab untuk mengeluarkan zakatnya(Irmawati, 2016). Pinjaman tanpa bunga (qardu alHasan) ini lebih meringankan kepada mereka yang tidak mampu sehingga mereka tidak terbebani dengan pengembalian yang harus disertai dengan bunga seperti pinjaman di bank dan lain-lain. Dr. Yusuf al-Qaradawi dalam kitabnya figh al-Zakah berkata: "saya berkeyakinan bahwa qiyas yang benar dan maksud umum dalam ajaran Islam adalah memperbolehkan kepada kita untuk memberikan pinjaman kepada orang yang membutuhkannya dari bagian gharim. Tetapi harus diatur sebaik-baiknya dan sehingga dengan itu bisa dibagikan dengan praktis dan memerangi riba serta menghapuskan segala bentuk bunga ribawi. Hal ini jelas sekali bahwa untuk membangkitkan kembali semangat tolong menolong, maka umat Islam harus mengembangkan dana-dana zakat untuk mengangkat perekonomian masyarakat miskin.

Meskipun dana yang diberikan oleh BAZNAS dalam bentuk bantuan modal masih sangat sedikit namun dengan dana itu mereka bisa membuka usaha kecilkecilan untuk menutupi kebutuhan sehari hari mereka(Hayana, 2016). Zakat bisa berdaya guna dan berhasil guna tentu saja harus diiringi dengan pengumpulan zakat yang maksimal, sehingga dana yang didistribusikan dalam bentuk bantuan modal bergulir angkanya bisa lebih besar. Bantuan modal yang besar bukan hanya akan menjadikan usaha mereka untuk memenuhi kebutuhan rumah-tangga para msutahiq tetapi bisa mengangkat derajat mereka menjadi muzakki.

\section{PENUTUP}

\section{Kesimpulan}

Studi tentang zakat akan selalu menarik karena disamping zakat ini adalah ibadah mahdah yang diwajibkan kepada seorang muslim yang mempunyai nisab juga karena zakat mempunyai dimensi sosial untuk memberikan kesejahteraan kepada masyarakat miskin atau yang tidak mampu. Inilah kelebihan syariat islam yang tidak individualis tetapi harus senantiasa memiliki kepedulian sosial. BAZNAS kabupaten Maros sebagai salah satu petugas zakat yang diamanahkan oleh undang-undang no. 23 tahun 2011 tentang pengelolaan zakat melakukan salah satu tugasnya yaitu pendistribusian zakat yang tentu saja sasarannya adalah sesuai yang digariskan oleh syariat islam bahwa zakat itu diperuntukkan delapan golongan. Pendistribusian yang 
dilakukan oleh BAZNAS tidak saja satu bentuk tetapi ada beberapa bentuk yang pertama pendistribusian dalam bentuk konsumtif yang membantu orang-orang miskin yang tidak mampu lagi bekerja, untuk memenuhi kebutuhan sehari-hari mereka, kedua adalah pendistribusian dalam bentuk produktif diburikan kepada orang-orang yang mampu berusaha hanya karena mereka tidak mempunyai modal atau kekurangan modal maka BAZNAS memberikan kepada mereka bantuan modal. Tujuan dari pendistrusian ini tentu saja untuk memberikan kesejahteraan kepada masyarakat miskin ini bahkan tujuannya adalah menjadikan mereka dari mustahik menjadi muzakki. Pendistribusian yang dilakukan oleh BAZNAS menurut penulis sudah sangat baik dengan melakukan diferensiasi sehingga tujuan zakat bisa tercapai, hanya saja memang dalam melakukan pendistribusian masih terkenda dikarenakan zakat yang terkumpul masih sangat terbatas

\section{Saran}

Rekomendasi untuk memaksimalkan pendistribusian zakat Badan Amil Zakat Nasional kabupaten Maros agar terus berupaya untuk memaksimalkan potensi zakat yang ada di Kabupaten Maros dengan terus melakukan koordinasi dengan Unit Pengumpul Zakat di setiap instansi yang ada.

Merekomendasikan kepada para pengambil kebijakan untuk memperkuat lembaga amil zakat ini sehingga mampu menjadi mitra pemerintah dalam mensejahterakan masyarakat miskin

Kebijakan pelaksanaan pengumpulan, pendistribusian dan pendayagunaan zakat yang dilaksanakan oleh Badan Amil Zakat Nasional Kabupaten Maros dijadikan model atau percontohan bagi daerah-daerah lain di provinsi Sulawesi Selatan khususnya dan di wilayah Republik Indonesia pada umumnya.

\section{DAFTAR PUSTAKA}

Aisyah. (2019). Pengelolaan Dana Zakat Dalam Pengembangan Usaha Mikro Binaan Baznas Kabupaten Enrekang. Jurnal la maysir.

Akhmad, M. (2013). Analysis of Factors Affecting Compliance Level of Paying Zakat: A Case Study in Bogor Regency . Jurnal alMuzara'ah.

Az-Zuhaili, W. (2011). Fiqih Islam Wa Adillatuhu terj. Abdul Hayyie alKattani, dkk, Jakarta: Gema Insani. Cet. Ke-1, jilid 3
BPS. (2019). Badan Pusat Statistik. Retrieved from https://www.bps.go.id/

Hilman, T. (2018). Eksistensi Zakat Sebagai Instrumen Dalam Upaya Menyeimbangkan Dan Pemerataan Ekonomi Masyarakat . Mumalatuna Jurnal Syariah.

Irfan Syauki, B. (2015). Analisis Peran Zakat dalam Mengurangi Kemiskinan : Studi Kasus Dompet Dhuafa Republika . 
Jurnal Pemikiran dan Gagasan.

Lestari, Alfi. 2015. Efisiensi Kinerja Keuangan Badan Amil Zakat Daerah (BAZDA): Pendekatan Data Envelopment Analysis (DEA). Jurnal Ekonomi dan Studi Pembangunan, Universitas Muhammadiyah Yogyakarta, Vol. 16, No. 2, 2015

Mujahidin. (2018). Efektifitas Pengumpulan Zakat Profesi (Studi Pada Baznas Di Kabupaten Maros). Jurnal PALITA.

Nasher, A. (2019). Analisis Efisiensi Organisasi Pengelola Zakat Nasional Dengan Pendekatan Data Envelopment Analysis. Jurnal Tazkia.

Patmawati. (2018). Pembangunan Ekonomi Melalui Agihan Zakat: Tinjauan Empirikal. jurnal syariah.

Qardhawi, Y, 2011. Hukum Zakat (terj. Salman Harun dkk), Jakarta: PT. Litera PintarNusa, jilid 1.

Sanep, A. (2015). Persepsi Agihan Zakat dan Kesannya terhadap Pembayaran Zakat Melalui Institusi Formal. Jurnal Ekonomi Malaysia.

Sanep, A., Hairunnizam, W., \& Adnan, M. (2016). Penswastaan Institusi Zakat dan Kesannya terhadap Pembayaran Secara Formal di Malaysia. Jurnal IJMS.

Sartika, M. (2018). Pengaruh Pendayagunaan Zakat Produktif terhadap Pemberdayaan Mustahiq pada LAZ Yayasan Solo Peduli Surakarta. Jurnal La Riba.

Supanra, M. D. (2014). Revolusi Zakat \& Revitalisasi Baitulmaal. Yogyakarta. Genta Press
Undang-Undang. (1999). tentang pengelolaan zakat. Jakarta.

Undang-Undang. (2011). tentang Pengelolaan zakat. Jakarta.

Yoghi Citra, P. (2015). Peran Zakat Dalam Penanggulangan Kemiskinan (Studi Kasus : Program Zakat Produktif Pada Badan Amil Zakat Nasional). The Journal of Tauhidinomics. 
Mujahidin, Tinjauan terhadap ..........

168|AL-TIJARY, Vol. 4, No. 2, Juni 2019 